\title{
PRÉVOIR - SAVOIR - POUVOIR CZYLI OD PRZEWIDYWANIA DO WIEDZY I WŁADZY
}

Kazimierz Krzysztofek

Instytut Nauk Społecznych, Uniwersytet SWPS

Im bardziej staramy sie skolonizować przysžtosić, tym wieksza szansa, że nas ona zaskoczy.

(Beck, Giddens, Lash 2009: 82)

\section{/// Wprowadzenie}

Przyjmuję w tym artykule nowe technologie za istotny czynnik sprawczy zmiany społecznej, politycznej, ekonomicznej i kulturowej. Nie rozważam innych istotnych zmiennych - bo to byłoby niewykonalne w artykule - takich jak procesy globalizacji, zmiana klimatu, nierówności społeczne, bezrobocie, migracje/uchodźcy, problemy demograficzne (starzenie się społeczeństw Północy), fundamentalizmy/terroryzm, kryzys finansowy, energia niskowęglowa, dostęp do zasobów (woda), zmiany kulturowe, w tym rosnąca skala wielokulturowości i in. Rewolucja technologiczna, zwłaszcza w sferze informacyjno-komunikacyjnej, pozostaje w ściślejszym lub luźniejszym związku ze wszystkimi wymienionymi tu zjawiskami.

Refleksja nad przyszłością (przyszłościami) z perspektywy technologicznej wymagałaby zastanowienia się nad kluczowymi pytaniami, spojrzenia na dorobek teoretyczny, metodologiczny i empiryczny wedle kilku kryteriów czy perspektyw, których tu nie sposób omówić, a które można zasygnalizować, zatrzymując się przy kilku aspektach.

- Po pierwsze: ile w myśli o przyszłości jest mniej lub bardziej utopijnych czy dystopijnych, a ile realistycznych prognoz rozwoju społeczeństwa?; 
- Po drugie: na ile przyszłość kreowana jest przede wszystkim przez wielkich aktorów (rządy i korporacje), a na ile skłonni jesteśmy upatrywać w zachodzących zmianach nowego ekosystemu jako ładu oddolnego, mocno ugruntowanego, w przeciwieństwie do ładu odgórnego, który okazuje się bardziej kruchy?;

- Po trzecie, czy bardziej przydatna jest perspektywa determinizmu technologicznego, czy konstruktywizmu społecznego, czyli nie tylko społecznego tworzenia rzeczywistości, lecz także technologii. A może mamy tu do czynienia z jeszcze czymś innym, jakimś „konstruktywizmem w determinizmie"?;

- Po czwarte, na ile uznamy nowe technologie za substancję socjoaktywną, na ile zaś dostrzeżemy - jak Alain Touraine w swej ostatniej książce (2013) - zagrożenia dla samego istnienia społeczeństwa; słowem, czy jest to nadal społeczeństwo, czy już bliżej nieokreślone postspołeczeństwo, w którym obok aktorów ludzkich, działają także aktorzy nie-ludzcy (Latour 1996: 365-381)?;

- Po piąte, jeśli postrzegamy wpływ technologii jako czynnik prospołeczny, to czy skłonni jesteśmy raczej sądzić, że mamy do czynienia z nowym społeczeństwem, czy odnotowujemy zmiany, ale z elementami ciągłości, czy też przewidujemy więcej kontynuacji niż zmiany?;

- Po szóste, jaka jest ontologia nowej rzeczywistości: czy wyłącznie naturalna, czasoprzestrzenna, dająca się wyjaśnić wyłącznie działaniem praw przyrody, bez zewnętrznej racji istnienia, którą zakłada transcedentalizm?;

- Po siódme, jakie sa główne kryteria aksjonormatywnej ewaluacji przeobrażającego się społeczeństwa; na ile postrzegamy je jako dalszy etap postępu, a w jakim stopniu widzimy w niej znamiona regresu; czym staje się osoba, jednostka ludzka: czy nadal należy ją ujmować w kategoriach humanizmu, wyłącznego sprawstwa; czy te kategorie już nie wystarczą? Czy w ogóle warto to roztrząać, czy nie lepiej poprzestać na neutralnej aksjologicznie diagnozie i deskrypcji?

Przeprowadzono mnóstwo badań mających na celu pozyskanie wiedzy, czym są nowe technologie, zwłaszcza cyfrowe, i jaka przyszłość one niosa, jak użytkownicy z nich korzystają, czy poszerzają one wolność, czy raczej zniewalaja, czy przynosza ze sobą więcej dobrodziejstw, czy zagrożeń, czy raczej humanizują i hominizują nasz gatunek, czy wręcz przeciwnie - odmóżdżają i ogłupiają; czym jest wirtualność i jakie konsekwencje 
dla wszystkich dziedzin życia niesie, jaka wyłania się morfologia z najnowszej myśli dzisiejszych społeczeństw, co już wiemy, a czego nie wiemy, czy są zjawiska w ogóle niedostrzegane, których nie jesteśmy w stanie nazwać, ponieważ nawet nie wiemy o ich istnieniu, jakich zjawisk w przeszłości w ogóle nie zauważyliśmy, a nawet jeśli zauważaliśmy, to nie potrafiliśmy ich zdefiniować. To tylko przykładowa lista zagadnień. Zakres tematyzacji i problematyzacji myślenia o przyszłości jest o wiele szerszy. W tych ramach interpretacyjnych i konceptualnych plasuje się zdecydowana większość dyskursów o przyszłości. Każdy z nich wymagałby gruntownego rozwinięcia, na które jednak nie ma tu miejsca.

Panuje niewiara w możliwość przewidywania przyszłości, ponieważ z reguły nie udaje się jej przewidzieć. Jednak to przewidywanie było i jest imperatywem kategorycznym. „Mózg człowieka nieustannie próbuje przewidzieć przyszłość i aktualizuje swoje oczekiwania, aby były zgodne z rzeczywistością" (Kwon 2018: 22-23).

Wymyślano w przeszłości wiele scenariuszy, po to aby obniżyć barierę postrzegalności nowych zjawisk. Im więcej scenariuszy, tym większe prawdopodobieństwo, że jeden z nich okaże się trafiony, ale tym większa niepewność, który z nich będzie koniem, na którego się postawi. Szanse daje rysowanie takich scenariuszy z wielu perspektyw, interdyscyplinarnie i transdyskursywnie, ponieważ wtedy można widzieć na raz „więcej słonia”, bowiem z perspektywy jednej dyscypliny można widzieć tylko jego kawałek, czyli odkrywać jakieś szczątkowe elementy rzeczywistości. To wszystko sprawia, że mamy mnóstwo ujęć i interpretacji, w których można się pogubić. Niniejszy artykuł oferuje z konieczności skrótowy przegląd tych rozmaitych ujęć i interpretacji. Uznaję jednak za celowe ich naszkicowanie jako klasyfikację nowych problemów badawczych.

Jeśli nie jesteśmy w stanie zdiagnozować i odczytać głębszych pokładów teraźniejszości, która jest empirycznie eksplorowalna, to cóż dopiero mówić o przyszłości, która jest nieempiryczna, bo nie istnieje, nie ma żadnego statusu ontologicznego. Ale czy rzeczywiście nie istnieje? Można znaleźć argumenty na poparcie tezy, że jednak istnieje, jeśli na przykład handluje się papierami wartościowymi futures czy produktami, które nie zostały jeszcze wytworzone. Można w skali mikro powiedzieć, że przyszłość już jest znana, jeśli czujnik trackera ciała pokaże nieuchronny zawał serca za jakiś czas, nieraz na dość długo przed odczuwaniem bólu.

Jak przewidywać jednak zmiany w czasie i przestrzeni wirtualnej? Tu skazani chyba jesteśmy na predykcyjny imposybilizm. Cała tradycja prognozowania przyszłości opierała się na badaniu trendów w rzeczywistości 
trójwymiarowej. A obecnie mamy do czynienia - jeśli nie z n-wymiarową - to z pewnością z większą liczbą wymiarów. Do rzeczywistości wirtualnej, cyberprzestrzeni niefizycznej i pozaczasowej przenosi się coraz więcej sfer aktywności ludzkiej: ekspresyjnej, ludycznej, poznawczej, instrumentalnej i in. Wirtualność nie jest nierzeczywistością.

Można ja pod pewnymi względami uznać za przyszłość zakodowana w genach, nasionach, projektach itp. Tu często przywołuje się film Spielberga Raport mniejszości - przewidywanie popełnienia przestępstwa (pre-crime) zanim zostało popełnione i podejmowanie odpowiednich działań prewencyjnych przez policję, co jest praktyką stosowaną eksperymentalnie w niektórych stanach USA. Czy to jest jednak nieuchronna przyszłość, czy tylko predykat? Mówimy tu tylko o skali mikro, a o przyszłości należy mówić także w skali mega, makro i mezo. Im większa skala, tym trudniej cokolwiek przewidywać, zwłaszcza na dłuższą czy nawet średnią metę. Modelowanie przyszłości odległej pochłania mnóstwo danych i informacji, których jeszcze nie mamy. Nie da się wykazać, że coś zaistnieje czy nie zaistnieje. Przyszłość jest łatwo przewidywalna, gdy jest zdeterminowana przez prawa przyrody, np. siłę grawitacji. Wiemy, że woda zawsze spływa w dół, ale możemy wiedzieć którędy, jeśli znamy dokładne ukształtowanie terenu.

Przyszłość następuje w różnym czasie i w różnych lokalizacjach inaczej, co przywodzi na myśl intuicje Williama Gibsona, że o przyszłości nie da się nic nowego powiedzieć. Przyszłość jest teraz, tylko nierówno rozłożona. Wynika stąd, że będzie wiele przyszłości.

Jak zatem modelować przyszłość? Słabość modelowania było już widać przy wielkich prognozach w epoce nowoczesnej, przemysłowej, gdy wiele rzeczy wydawało się przewidywalnych, gdy mieliśmy do czynienia z jakąś równowaga ciagłości i zmiany, gdy instytucje wydawały się stabilne. W epoce industrializmu znane były trendy we wszystkich skalach. Były nimi: industrializacja, urbanizacja, alfabetyzacja - generalnie pod piecza państwa, które kierowało się ideologią modernizacji, budowania siły narodu. Trendy było dość łatwo przewidywać w porównaniu z czasem obecnym. Jak twierdzą Giddens, Beck, Lash i inni modernizacja przemysłowa - maszyn, fabryk, taśm produkcyjnych, hierarchii - nie wymagała refleksyjności od wykonawców, modernizacja w późnej nowoczesności jest modernizacją refleksyjną, wymaga adaptacji proaktywnej i myślenia, każdy może mieć potencjalnie wpływ na jej kształt (Giddens, Beck, Lash 2009: 222). Structure driven change jest silnie skorelowana przez individual driven change. Im bardziej społeczeństwo się modernizuje, tym bardziej aktywne jednostki (podmio- 
ty) nabywają zdolności wywierania wpływu na warunki społeczne swojego istnienia, „uwalniają" się od struktur społecznych charakterystycznych dla nowoczesności.

W przyrodoznawstwie wszystko wydawało się zrozumiałe dzięki fizyce Newtona, logice wynikania przyczynowo-skutkowego. Świat jawił się jako maszyna, której wszystkie części były znane, podobnie jak prawa mechaniki i zasady działania mechanizmu. A tu nagle pojawiają się kwanty, „kot Schroedingera", splatania, superpozycje. Postrzegany w trzech wymiarach świat stał się nieoczywisty, bo nazbyt uproszczony, cząstka elementarna może się znajdować w wielu stanach równocześnie, rzeczywistość subatomowa rządzi się innymi prawami, zmienia się nie tylko w czasie, lecz także pod wpływem jej obserwowania. Sytuacja badaczy trendów społecznych przypomina sytuację przedstawicieli „twardych” nauk - scientists. Tak jak społeczeństwo jest płynne, zmienia się w trakcie, a często także pod wpływem badania, tak zmienia się także rzeczywistość fizyczna, co pokazuje fizyka kwantowa. Można zatem powiedzieć, że fizyka nowej generacji zaczyna mieć podobne problemy poznawcze jak przedstawiciele humanistyki i nauk społecznych. Foton będący raz czastką, a raz falą zmienia się pod wpływem jego obserwowania przez badacza. Obiekt badania zaczął podlegać imperatywowi zmienności i to w czasie samego badania.

\section{/// Złożoność i emergencje}

To jeden z dowodów na to, że rozstaliśmy się ze światem jako systemem prostym, a weszliśmy w nielinearny układ dynamiczny, czyli system złożony, który wytwarza zjawiska emergentne. A tych nie sposób przewidzieć, a jeśli już się pojawia, to nie potrafimy ich opisać na gruncie znanego języka i wyjaśnić na gruncie posiadanej wiedzy. System złożony może się składać z elementów, które w pojedynkę są proste, ale całość staje się złożona na skutek powiększającej się wykładniczo liczby interakcji między nimi i potęgowania rozkładu relacji, jak to ma miejsce w sieci, na rynku, giełdzie itp. Linearny przyrost interakcji w którymś momencie wywołuje przejście fazowe, co oznacza inna jakość. Molekuły wodoru i tlenu nie są mokre i przeźroczyste, ale stają się takie po przekroczeniu pewnej skali i na tym właśnie polega emergencja. Fizycy nie wiedza, jak do tego dochodzi.

Można wręcz powiedzieć, że ta struktura jest tak dynamiczna, iż sama staje się procesem, a to, co nazywamy struktura, jest tylko stopklatką pewnego stanu, który za chwilę jest innym stanem. Do opisu tej złożoności używa się wielu pojęć takich jak zaburzenia, chaos i brak pewnych instytucji, 
które pomogłyby go oswoić; krach, niestabilność, nieład zglobalizowany, porządek planetarny, transpaństwowy, transnarodowy, transgraniczny, turbulencje, terroryzm, erozja granic, interkulturowy, transkulturowy, aktorzy transnarodowi, mnogość, wielogłos, fragmentacja, rozpady, przepływy, prądy, linki, sieci, turbulencje, bifurkacje, atraktory, fraktale, strumienie, napięcia i konflikty. Procesy, które się pod tymi pojęciami kryją, zawierają ogromna ilość koniunkcji - powiązań i zależności miedzy różnymi poziomami społeczeństwa, ekonomii, kultury - a coraz mniej dysjunkcji. Świat jawi się jako „burza magnetyczna”. Wiele sił przyciaga naraz, najbardziej na biegunach, stąd coraz ostrzejsze konflikty. Takimi słowy wyraził to Edgar Morin w książce Pour sortir du XXe siècle [,Jak wyjść z XX wieku”]:

[...] zmiany, dewiacje, twórcze dokonania, nagłe zerwanie z przeszłością, chaos i kryzysy [...] w tym wirze innowacji / dewiacji / tendencji / kontrtendencji / konfliktów / wstrząsów/ kryzysów, które współtworzą proces stawania się, dochodzi do nawrotów i zawrotów, cele stają się środkami i vice versa [...]. Żadnego czynnika nie można uznać za wartość stabilną, trwała, dająca się wyizolować w badaniu konkretnego wycinka jakiegoś procesu, niczego więc nie można przewidywać na pewno, wszystko trzeba przepowiadać warunkowo (Morin 1981: 324-325).

W spekulowaniu nad przyszłością możliwa i jedynie poprawna jest tylko ekstrapolacyjna analiza trendów, które już istnieją ${ }^{1}$. Można wyspekulować pojawienie się nowego trendu, ale to raczej udaje się intuicjonistom, bardziej artystom niż badaczom stosującym rygorystyczną metodologię. Można podać wiele przykładów na to, jak intuicje artystów, pisarzy wyprzedzały wielkie odkrycia czy wynalazki, by przywołać Juliusza Verne’a, Phillippa K. Dicka, Michaela Crichtona czy Stanisława Lema. Ten ostat-

\footnotetext{
${ }^{1}$ Wiele zależy od tego, na ile uda się zidentyfikować „punkt przełomowy” (tipping point, Gladwell 2005) i rozpoznać nowy wzorzec procesu (pattern recognition, Gibson 2005). W Raporcie Światowego Forum Ekonomicznego (World Economic Forum 2015) 800 ekspertów tak wyobrażało sobie przyszłość w 2025 roku: 10\% mieszkańców planety będzie nosić odzież podłączoną do Internetu $(91,2 \%$ wskazań). W USA pojawią się pierwsi robotyczni farmaceuci $(86,5 \%)$. Pierwszy model samochodu wydrukowanego w 3D wejdzie do produkcji (84,1\%). 5\% dóbr konsumpcyjnych będzie drukowanych w 3D (88,1\%). 90\% światowej populacji będzie regularnie korzystać z Internetu (78,8\%). 10\% samochodów autonomicznych (bez kierowcy) będzie jeździć po drogach USA $(78,2 \%)$. Przeprowadzona zostanie pierwsza transplantacja wątroby wydrukowanej w 3D (76,4\%). Ponad 50\% ruchu internetowego pochodzić będzie od domowych urządzeń $(69,9 \%)$. Na mapie globu pojawi się pierwsze miasto, w którym nie będzie sygnalizacji świetlnej (regulacja przez smart vehicles) (63,7\%). Pierwsza smart macbine zasiądzie w Radzie Dyrektorów korporacji $(45,2 \%)$. Większość z tych prognoz to ekstrapolacja istniejących już trendów.
} 
ni wykreował w swoim umyśle wyobrażenie rzeczywistości, którą nazwał w latach 60. ubiegłego wieku fantomatyczna, a która - wypisz wymaluj była prefiguracją rzeczywistości wirtualnej, tak jak się ją percypuje w wieku Internetu. Takie wizje bywają inspiracją dla scientists. Lema Fantastyka i Futurologia (2009) jest przykładem dzieła, które z sukcesem staje w szranki z naukową futurologia i udowadnia przydatność literackiej fikcji w modelowaniu przyszłości człowieka. Naukowa futurologia - termin wymyślony przez O. K. Flechtheima w 1943 roku - miała zajmować się przyszłością, lecz nie tyle czczym prognozowaniem, ile wartościowaniem przewidywanych trendów. Boom przypadł na lata 60. i 70. Największy rezonans wywołała książka Hermana Kahna i Anthony Wienera The Year 2000 streszczająca prace wybitnych uczonych zasiadających w komisji powołanej przez Akademię Sztuki i Nauki w celu naukowego przewidzenia, jak będzie wyglądał świat na przełomie tysiącleci (Kahn, Wiener 1967).

Problemem dla badaczy trendów jest nie tyle rozpoznanie wektorów, ile tego, co wynika z ich wypadkowej i - co najtrudniejsze - jak i czy w ogóle można je wartościować wedle dzisiejszych kryteriów. W tym momencie mogą dawać słodkie owoce, ale w przyszłości mogą okazać się gorzkie, czy wręcz zatrute. Wynika stąd ważne przesłanie metodologiczne dla badaczy. Przestarzałe stają się metody, które ujmują następstwa zjawisk w paradygmacie przyczyna-skutek, a bardziej obiecujące - te które postulują stosowanie metod uwzględniających złożoność i dynamikę procesów wynikających z najróżniejszych korelacji, potęgowego rozkładu relacji w sieciach $\mathrm{i}$ innych. Sytuacja komplikuje się m.in. z tego powodu, iż rzeczywistość społeczna nie jest już tylko efektem działania ludzkich aktorów, lecz także nie-ludzkich (non-buman), np. maszyn, które wchodzą między sobą w relacje (tzw. Internet rzeczy) i maja wpływ na ludzi. W warunkach takiej złożoności bardzo trudno jest prognozować, bo światem rządzi chaos deterministyczny. Drobna ledwo uchwytna zmiana w układzie początkowym (jak ruch skrzydełek motyla) wywołuje nieproporcjonalnie wielkie zmiany „na wyjściu" (jak w układach pogodowych). Ale jednak mamy tu do czynienia z jakimś determinizmem. Chaos jest czymś innym niż nieład, nie da się w nim tej relacji uchwycić, mamy bowiem do czynienia ze stochastycznością, przypadkowością, strukturami dysypatywnymi. Nawiązując do historycznej metafory, znaleźliśmy się już na drugiej połówce szachownicy, na której nie da się policzyć ziarenek ryżu, te wielkości stają się bowiem niewyobrażalne.

Istnieje problem z językiem opisu rzeczywistości, który się zestarzał, a więc $\mathrm{w}$ istocie $\mathrm{z}$ wyczerpywaniem się paradygmatu. Człowiek już 
nie myśli, a przetwarza. Komputer staje się metaforą mózgu. Przykładem wprowadzenia nowego języka do analizy procesów różnicowania się społeczeństw jest metafora struktury społecznej jako kłącza. Ta płynna struktura pozbawiona jest wyraźnego centrum, gdzie ludzie budują swoje kontakty na podstawie własnych wyborów i strategii. Struktura kłączowa, czy kłączopodobna (rizomatyczna), to struktura nielinearna, polifoniczna, anarchiczna i nomadyczna (Deleuze, Guattari 1987). Z każdego kłącza „łodygi” może wyrosnąć coś, co przechwyci energię zmiany, ale nie jesteśmy w stanie przewidzieć z którego miejsca. Bardzo to komplikuje wszelką probabilistykę. W świecie rizomatycznym mamy mnóstwo wektorów zmian, często opozycyjnych wobec siebie, i nie wiemy, jaka jest ich wypadkowa. Logika binarna dwuwartościowa zawodzi, potrzebna jest logika rozmyta (furzy logic). Arystotelesowskie pojmowanie prawdy - jako adequatio rei et intelectu - nie wytrzymuje próby czasu, gdy rzecz może być w dwu, a nawet wielu różnych stanach.

Świeżą myśl w tej kwestii proponuje Nassim Nicholas Taleb. Zajmuje się on etiologią kryzysów, istotą zmienności i kalkulowaniem ryzyka w czasach, w których nie można w sposób linearny przewidywać przyszłości. Dostrzega on źródła kryzysów w mentalnym nawyku, że należy się liczyć z wystąpieniem tego, co najbardziej prawdopodobne, i lekceważeniu tego, co najmniej prawdopodobne. Autor posługuje się metaforą czarnego łabędzia, którego istnienia nikt nie dopuszczal, dopóki go ktoś po raz pierwszy nie zobaczył. Czarny łabędź jest tu metaforą niezwykle rzadkiego zdarzenia, znajdującego się na samym krańcu krzywej rozkładu prawdopodobieństwa, ale wywierającego olbrzymi wpływ na otoczenie. Takim „czarnym łabędziem” był terrorystyczny atak 11 września 2001 roku. Trzeba się oswoić z tym, że w złożonym świecie takich „łabędzi” będzie coraz więcej, może będą raczej szare niż czarne; trzeba się też liczyć, że coraz częściej przeważać będzie to, co nieznane, przypadkowe i zmienne (Taleb 2015).

Rośnie skala trudności, ale właśnie dlatego istnieje potrzeba prognozowania, aby mieć w ręku świeczkę z wątłym płomieniem, który w każdej chwili może zostać zdmuchnięty, ale choćby na chwilę i na krótki dystans oświetla drogę do przebycia. Chodzi o obniżanie bariery postrzegalności trendów, zagrożeń, wczesne ostrzeganie i ujawnianie szans, bo to kwestia przetrwania w złożonych ekosystemach, szanse na bycie konkurencyjnym, dzięki wczesnemu odkryciu jakiegoś trendu. Ponieważ tzw. czysty forecast bywa zawodny, większe nadzieje pokłada się w czymś, co się określa jako foresight. Różnica między jednym a drugim jest taka, jak - mówiąc słowami Tadeusza Kotarbińskiego - między „domyślaniem się” przyszłości a jej 
„obmyślaniem”. W tym drugim przypadku chodzi o to, aby - poznawszy potrzeby ludzi, opinie ekspertów metodą delficką, burzy mózgów, krzyżową analizą wpływów i innymi - skierować gros posiadanych środków na te sfery rzeczywistości, na które chce się mieć wpływ, a nie liczyć tylko na czcze prognozowanie. W ten sposób wywarł wielki wpływ na rzeczywistość społeczną Apple ze swym smartfonem, choć z pewnością Steve Jobs nie miał pojęcia, jaki kształt tej rzeczywistości się wyłoni pod wpływem praktyk społecznych, negocjowania i nadawania technologii nowych znaczeń przez użytkowników. Myślenie deterministyczne w przypadku technologii zawodzi, nowe kształty zależą od społecznego tworzenia rzeczywistości, co w języku SCOT (Social Construction of Technology) nazywa się społecznym tworzeniem technologii. Jednym z trendów, co do dynamiki którego jesteśmy pewni, jest akceleracja zmian, która w połączeniu z innym oczywistym trendem: digitalizacja (obydwa się nawzajem napędzaja), wyczynia niestworzone rzeczy. Przede wszystkim skraca dystans między science i fiction. To, co jeszcze przed chwila było przedstawiane przez twórców jako sci-fi, staje się realnym bytem. „Przyszłość staje się przez cały czas”, a technika ciagle przyspiesza swą ewolucję. Postęp naukowy dogania spekulacje fantastów (Wójcik 2018: 10). Z science fiction jest jednak taki problem, że często snuje się zbyt fantastyczne wizje (przysłowiowe latające samochody, wyleczalność wszystkich możliwych chorób), by z kolei nie doszacować wielu innych kształtów przyszłości, które stały się już rzeczywistością.

Skracanie dystansu czasowego między fikcja przyszłości a realnością zawdzięczamy sztucznej inteligencji, eksperymentom z systemami wieloagentowymi, nowej nauce sieci z obietnica predykcji (Barabási 2010), informatyce neurokognitywnej, a nade wszystko data science. Nadzieję pokłada się w potężnych symulatorach Ziemi. Jednym $z$ nich jest finansowany przez UE Symulator Żywej Ziemi (Living Earth Simulator) (patrz: FuturICT Project 2016), który pozwoli poradzić sobie z pęczniejącą masa danych o społeczeństwach, tak aby socjologia, ekonomia, epidemiologia i inne nauki społeczne miały taki sam komfort jak fizyka i inne nauki ścisłe. Zagregowanie danych o ludziach w połączeniu ze społeczną i geofizyczna fotografia planety ma pozwolić na nową jakość - symulowanie zachowań ludzkich społeczeństw wraz z ich fizycznym środowiskiem (i łatwość wizualizowania tych symulacji, co je bardziej uwiarygadnia) dzięki sensoryzacji („oczujnikowaniu”) niemal wszystkiego: ludzi, domów, miast, skał, chmur, oceanów, które znajdą się w jednej wszechogarniającej cyfrowej chmurze danych. Oznaczałoby to, że społeczeństwo, wszystkie sfery jego życia, da się umieścić w przyszłości w laboratorium cyfrowym, a wtedy przewidy- 
wanie stanie się nauką ścisła. Wedle raportu Think Tanku Gartner (2016) jeśli przyszła gospodarka, a w perspektywie także inne dziedziny życia, będą w stu procentach ucyfrowione, to będzie to oznaczać programowalne społeczeństwo. Wiedza o społeczeństwie stanie się „fizyką społeczną” lub socjofizyką, dziedziną nauki, która posługuje się matematycznymi narzędziami w celu badania i rozumienia zachowań ludzkich, indywidualnych i zbiorowych (Pentland 2015).

Interesująca intuicją wykazał się Jean Baudrillard (2001), którego zdaniem nasza rzeczywistość - środowisko życia zapośredniczone przez media, technologie - staje się coraz bardziej „obsceniczna”. Jest taką dlatego, że technologie czynią ją bardziej widzialną niż rzeczywistość fizyczna, wydzierając tajemnice ludziom, przyrodzie, światu. Nic się już przed nimi nie ukryje: ani priony, ani bakterie czy kopulujące mszyce. Owa nakładka cyfrowa na ludzi, przyrodę, kosmos, dno oceanów itp. ma ujawniać potencjalnie wszystkie sekrety. Jest to coś w rodzaju uniwersalnego, przekraczającego wszystkie epoki WikiLeaks. Wydzieramy te tajemnice przyrodzie, ale także sobie samym, ujawniamy nasze zachowania, mobilność przestrzenną, ale także opinie, stany świadomości, pragnienia, zachwyt, obrzydzenie itp., nie tylko to, o czym myślimy, ale także to, co myślimy. Najbardziej opresyjni dyktatorzy nie wiedzieli tyle o swych poddanych.

Wyłania się przekonanie polityki, biznesu i data scientists, że większość problemów społecznych da się rozwiązać dzięki nowoczesnym technologiom, co Evgeni Morozov nazywa solucjonizmem i co ma oznaczać swoistą laboratoryzację społeczeństwa (Morozov 2013). Solucjonizm według Morozova jawi się jako system już nie tyle społeczny, ile socjotechniczny, w którym kluczem do wszystkiego jest odpowiednia liczba kliknięć. To zjawisko mieści się w logice rozwoju cywilizacji zachodniej od fazy industrializmu. Pokusa wykorzystania nauki i techniki do inżynierii społecznej istniała od początku ery maszyn. Miała ona zapewnić przewidywalność oraz kontrolę praktyk i procesów społecznych, powściągnięcie ich żywiołowej i potencjalnie destrukcyjnej natury.

Czyli przyszłość da się obliczyć, ergo stworzyć numeryczną teorię społeczeństwa - wymodelować, zaprogramować i zalgorytmizować, bo to kwestia maszyn o odpowiedniej mocy przetwarzania danych, ich zinterpretowania i uzyskania nowej wiedzy. Przebija w myśleniu o przyszłości duch Castellsowego informacjonizmu, który organizuje obecną rzeczywistość i nasze życie w niej, a także przyszłość. W przyszłości społeczeństwa jako całości będą świadomie zorientowane na tworzenie informacji 
i to będzie utrzymywać przy życiu całą cywilizację. Warto w tym kontekście wspomnieć o Vilémie Flusserze i jego idei programatyzmu (Flusser 1987). Programu nie wymyślił człowiek - wymyśliła go natura; wszystko jest programem: ewolucja, funkcjonowanie organizmów, a nawet wszechświat jako taki i jego przyszłość. Pobrzmiewa w tym wiara w technokrację, że świat da się zaprogramować jak taśmę produkcyjną, z tą modyfikacją, że jest to już raczej infokracja. Ten imperializm programu dobrze odzwierciedlił Jose Luis Borges w swej prognozie „Biblioteki Babel”, w której znajdą się wszystkie napisane przez program komputera (zapewne będzie to komputer kwantowy) książki, zdolny do stworzenia wszystkich możliwych kombinacji tekstów z istniejących kodów i znaków.

\section{/// Czy socjologia dysponuje „szklaną kulą”?}

Julian Simon, amerykański ekonomista, twierdził, w czasie gdy modne były pesymistyczne czy wręcz katastroficzne prognozy dla naszej planety ogołacanej z zasobów (m.in. Raporty Klubu Rzymskiego), że zasoby nie sa co prawda nieskończone, ale nieskończony jest geniusz człowieka, dzięki niemu ludzie zawsze coś wymyślą, żeby wykazać błędność tych prognoz (Simon 1981). Kiedyś Malthus też straszył katastrofą, ale na szczęście dzięki rewolucji umysłowej i przemysłowej oraz innowacjom, które one zrodziły, do tej katastrofy nie doszło. Powiada się, że w każdym czasie pieniądz rządził światem, ale ten pieniądz brał się z różnych rzeczy. W przeciagu dziejów krytycznymi zasobami byli niewolnicy, poddani, ziemia uprawna, następnie paliwa kopalne, energia elektryczna i in. Pojęcie zasobu jest relatywne, jest nim to, co w danej epoce stanowi najważniejszy aset rozwojowy. W epoce przedprzemysłowej węgiel i inne paliwa kopalne nim nie były, ponieważ nie uczestniczyły w rozwoju. Zasobów mogło zabraknąć, ale jeśli zabraknie inteligencji i wiedzy, jak sobie radzić z problemami i przeciwnościami, to wtedy nie ma się siły, aby stawić czoła zagrożeniom i wyzwaniom. Wiedza stała się w społeczeństwie późnonowoczesnym owym krytycznym zasobem i stąd ten szyld „społeczeństwo wiedzy”. To jest grunt dla innowacji.

Rodzi się znowu optymizm - wiara, że jeśli niemal wszystko można zważyć, policzyć, zmierzyć, to znaczy, że wszystko da się też zoptymalizować, o czym przed ponad wiekiem był przekonany James Taylor, twórca naukowej teorii zarządzania. Czyli wniosek jest prosty: jeśli wszystko można policzyć, to należy zawierzyć naukom przyrodniczym, inżynieryjnym, matematyce, za którymi stoi autorytet „twardych” nauk. A nie „roz- 
memłanej" hermeneutycznie socjologii, która pomna porażek w przeszłości utraciła wiarę w swój potencjał predykcyjny, utożsamiając predykcję ze spekulacja. To jedna z przyczyn, dla których socjologia była lekceważona. Narasta przekonanie, że data scientists sami sobie poradza, mając do dyspozycji wielkie złoża Big Data. Nie potrzeba im socjologów ani innych specjalistów dziedzinowych, bo sami uporają z interpretacją danych, ich destylowaniem, przetwarzaniem, agregowaniem, autentyfikowaniem, kontekstualizowaniem i będą potrafili dostarczyć odpowiednich policy czy business oriented recommendations.

Socjologia ma nadal niebagatelne zasoby, ale musi przekonać, także samą siebie, że bez niej nie poradzą sobie owi data scientists - twórcy nowej wiary - dataismu, jak ja nazywa Yuval Noah Harari (2017). Ten potencjał socjologii dostrzegają niektórzy przedstawiciele nauk ścisłych, m.in. Marc Buchanan (2010), zdaniem którego nauki społeczne przestaną być „ubogim krewnym". Warto zauważyć, że status science dla socjologii rezerwował już w latach 30. ubiegłego wieku Julian Huxley (1935).

Coraz więcej badań socjologicznych przynosi interesujące rezultaty, także w sferze przewidywania zachowań społecznych, by wymienić badania: L. Barabásiego (2002), Matthew J. Salganika, Duncana J. Wattsa (2009), V. Mayera-Schoenbergera, V. K. Cukiera (2013), A. Sitarama i B. A. Hubermana (2010). Sama socjologia też jednak sama nie da sobie rady, data scientists $\mathrm{i}$ inni badacze z obszaru nauk ścisłych sa potrzebni, żeby wreszcie zasypać stary podział, który opisał przed kilkudziesięciu laty Charles Percy Snow (wyd. 1993) w artykule Dwie kultury, między którymi nie ma interfejsu, jak powiedzielibyśmy dzisiejszym językiem. Wierzy w to m.in. John Brockman, orędownik „Trzeciej Kultury”, która zintegruje badaczy o różnych profilach (Brockman 2005: 25-36).

Pojawia się pytanie, czy socjologia powinna się pokusić o wizje, próby obmyślania nowego ładu, przed czym stroniła, aby nie narazić się na zarzut kreowania utopii społecznych. Stroniła pomna przestróg Karla Poppera, że kto obiecuje niebo na Ziemi, raczej ma szanse sprowadzić piekło. Ale wizjonerów nie brak, bo czymże, jeśli nie wizją, jest ideologia trans- i posthumanizmu, w których widzi się szanse na postęp 2.0. (więcej: Krzysztofek 2016: 329-371). Ktoś musi nadać gwałtownym zmianom technologicznym i społecznym jakiś sens, oswoić nową rzeczywistość, tę, która nadciaga, aby nie popaść w permanentny kryzys społeczny, w którym zatracają się bieguny wartości, grożące przeciagającym się turbulentnym i traumatycznym rozziewem między ładem oswojonym a niepewna przyszłościa. Jeśli 
socjologia nie weźmie w tym udziału, to będzie skazana na bycie w cieniu utopii kreowanej przez „kapłanów” z Doliny Krzemowej.

Musimy na nowo zrozumieć świat, tak jak ci, którzy zaczęli żyć po wynalezieniu prochu, druku, telewizji i innych przełomowych innowacji wywracających wszystko do góry nogami. Socjologia musi w tym pomóc. Najważniejsze z pytań, od których należałoby zacząć rozważania o przyszłości, brzmi: co wiemy o tym nowym świecie, co do czego mamy pewność, a jakie są obszary niepewności, czy wręcz niewiedzy, ignorancji i co z tego wynika dla naszej refleksji o jednostce i społeczeństwie. Ważna jest świadomość ograniczeń poznawczych i przydatności dotychczasowej wiedzy w rozumieniu obecnych procesów. Istnieje jakaś bariera przewidywalności: nie przewiduje się tego, co się uważa za niemożliwe. To duże ograniczenie. Klucz jest w wyobraźni. Przewidywać przyszłość to w dużym stopniu przewidywać rozwój nauki i wiedzy. Sama prognoza rozwoju technonauki niewiele nam powie o przyszłości, jeśli nie będziemy wiedzieć, co z nia zrobią ludzie w ich codziennych praktykach, próbach nadawania im sensu. Czyli odchodzimy od technodeterminizmu i kierujemy się w stronę konstruktywizmu społecznego.

Można pokusić się o swoistą retrognozę, co zaowocować może takim oto stwierdzeniem: wiedza o społeczeństwie w starożytności byłaby nieprzydatna do zrozumienia społeczeństwa feudalnego, wiedza o społeczeństwie feudalnym była nieprzydatna do opisu społeczeństwa przemysłowego, wiedza o społeczeństwie przemysłowym ma ograniczoną przydatność do opisu społeczeństwa poprzemysłowego nazywanego dziś najczęściej informacyjnym i sieciowym. Można mówić o niewielkiej lub ograniczonej przydatności wielu nurtów klasycznej myśli społecznej, m.in. teorii klas, narodu $\mathrm{i}$ in. Tradycyjne rozumienie klasy, narodu czy struktury społecznej, by wymienić najważniejsze, dziś nie wystarcza. Przydatne są natomiast dawno stworzone teorie wymiany, konfliktu, interakcjonizm społeczny, teorie dramaturgiczne.

Problemy z kreowaniem sposobów konceptualizowania i interpretowania nowych zjawisk społecznych biorą się także stąd, że - jak powiedzieliśmy - nie mamy już do czynienia z jedną megatendencją, jaką w społeczeństwie nowoczesnym były industrializacja i modernizacja. Mogłoby się wydawać, że obecnie także mamy do czynienia z jedną megatendencją, jaką jest przejście od społeczeństwa analogowego do cyfrowego, ale ta cyfryzacja to raczej powstawanie nowego ekosystemu, środowiska życia. Istnieje mnóstwo mikrotendencji, często o sprzecznych wektorach, co sprawia, że bardzo trudno określić czytelną wypadkową tych procesów. Sprawia to, 
że w określonych sytuacjach dwa sprzeczne sądy o rzeczywistości moga być prawdziwe lub fałszywe, społeczeństwa mogą się znajdować w wielu różnych stanach jednocześnie. Można tu przywołać twierdzenie Mikołaja z Kuzy o coincidentia oppositorum.

Pytanie o przydatność klasycznej myśli społecznej do wyjaśniania nowych procesów i zjawisk naturalnie nie wystarczy. Potrzebna jest także odpowiedź na pytanie, na ile nowa myśl wystarcza do tego wyjaśnienia. Przez nową myśl rozumiem nurty intelektualne, których twórcy mieli ambicję zmierzenia się z przejściem od społeczeństwa industrialnego do postindustrialnego. Tu od razu myśl kieruje się ku Alainowi Touraine’owi i Danielowi Bellowi. Ich propozycja nazwania społeczeństwa postindustrialnym była $\mathrm{w}$ istocie propozycją nowego paradygmatu, a w każdym razie nowego narzędzia epistemologicznego. Przymiotnik „postindustrialny” nie definiuje jednak pozytywnie nowego społeczeństwa, stąd liczne jego dookreślenia, z których na czoło wysuwają się dwa główne: „społeczeństwo informacyjne” i „społeczeństwo sieciowe”. Sa to jak dotychczas najbardziej całościowe, rozbudowane próby nazwania społeczeństwa epoki komputera i sieci. Teorie społeczeństwa informacyjnego (m.in. Beniger 1986) kładły nacisk na przetwarzanie informacji (processing), kiedy powstawały, nie było bowiem sieci w dzisiejszym kształcie, zaś teorie społeczeństwa sieciowego (Castells 2006, Barney 2008, van Dijk 2010) koncentrowały się na pracy sieci (networking). Z czasem rozwiązał się worek z nowymi nazwami teorii, często chodziło o "produkcję paradygmatów” i marketing naukowy. Można się spotkać z takimi określeniami jak: hiperspołeczeństwo, społeczeństwo technologiczne, pomasowe, mobilne, nomadyczne, transhumanistyczne, transparentne, algorytmiczne, postprywatne, okablowane, skomputeryzowane i in.

W nurcie krytyki tej „hydry”, który poddał rewizji tradycję oświeceniową i który bywa nazywana zbiorczo postmodernizmem, widzimy pokusę ucieczki w jakieś małe narracje, bliżej niesprecyzowane propozycje nazwania nowego ładu społecznego. Postmodernizm, niszcząc naukowe narracje, zepsuł klimat dla wykreowania jakiejś spójnej teorii społecznej na wiek XXI. Można w tych nurtach znaleźć sporo świeżych myśli, mają one jednak pewna wadę - nie rokuja nadziei na stworzenie koherentnej teorii krytycznej, która by mocno i przekonywająco chwytała zwrot cyfrowy i wynikające zeń zmiany społeczne w epoce komputera, sieci, neuronauki, sztucznej inteligencji, Internetu rzeczy, rzeczywistości rozszerzonej i czego tam jeszcze. Są to najczęściej słabo uporządkowane zbiory twierdzeń budowane wokół jakiejś miałkiej tezy (Bobryk 2014). Wystarczy „społe- 
czeństwo" opatrzyć jakimś przymiotnikiem i już jest teoria. A najlepiej użyć prefiksu post, który jest wytrychem i ma ukazać wiele z tego, co ma nastąpić w przyszłości: postspołeczeństwo, postpieniądz, postkapitalizm, postpraca, postprawda, która stała się dziś gwiazdą leksykalną, postczłowiek wreszcie.

Aktualny stan każdego systemu określa jego przyszłość, którą można prognozować jednak na krótką metę. Oznacza to dalej, że nie wystarczy rozeznanie w aktualnych trendach. Postrzeganie i identyfikowanie trendów, czyli określonych prawidłowości, które opisują dynamikę przekształceń, to jeden ze sposobów zrozumienia i porządkowania zmiennej rzeczywistości.

Samo słowo „trend” jest modną kategorią analityczną i opisową, często wartościowaną pozytywnie (samo słowo trend jest trendy: znaczy cool). Żyjemy w czasach bezprecedensowej zmienności zarówno w sferze osobniczej, społecznej, jak i pozaspołecznej (np. zmiany klimatyczne). Rozumienie istoty, etiologii, natury trendów zarówno w skali mega, makro, mezo i mikro jest warunkiem zrozumienia świata i procesów w nim zachodzących.

Widzimy gołym okiem, że nasze przyszłości są kształtowane przez dzisiejsze procesy, co do których jesteśmy pewni, że obecnie zachodzą i ich dynamika się nie wytraci na krótką ani też dłuższą metę, chyba że pojawi się jakaś zaburzająca zmiana, której nie można wykluczyć. Wiemy więc, że następuje i będzie następować cyfryzacja wszystkich dziedzin życia, że dziać się to będzie w warunkach rosnącej mobilności i nomadyczności naszego życia. Prowadzić to będzie nadal do dalszej artyficjalizacji otoczenia (coraz więcej artefaktów w naszym nowym ekosystemie, ze sztuczną inteligencją włącznie), akceleracji procesów, a za ich przyczyna do coraz większej złożoności i emergencji, która będzie produkować coraz więcej zjawisk nieprzewidywalnych, niemających natury liniowej - i dlatego właśnie nieprzewidywalnych.

Jeśli zatem proste myślenie linearne w schemacie ewolucyjnym zawodzi, to może należałoby się zwrócić w stronę myślenia w paradygmacie cyklu? Rozważanie problemu w duchu postępu czy regresu grzeszy linearnościa ujęcia: orzekamy, że coś zmierza w złym czy dobrym kierunku albo w jednym i drugim jednocześnie. Nie sprawdza się neoewolucyjny schemat trzech faz rozwojowych społeczeństw - od epoki przedprzemysłowej i przednowoczesnej przez nowoczesność-industrializm po ponowoczesność-postindustrializm, w którym to schemacie umieszcza się społeczeństwo informacyjne wraz z jego siłą napędowa - Internetem. Nie da się nieliniowego, rizomatycznego (kłączowego) kształtu przyszłego świata ulokować w liniowej koncepcji czasu, który ma dopiero nadejść, i w tej 
części przestrzeni, w której zajda wszystkie zdarzenia. Prefiksy pre i post narzucają takie myślenie, coś musi następować po czymś na mocy samych praw historii. Pojawia się więc pytanie, co to wszystko oznacza dla socjologii zmiany społecznej, gdy ta staje się normą, a ciagłość nienormalnością. Rodzi to problemy badawcze i poznawcze, a wręcz prowokuje do pytania, jak te procesy badać. Dziś, kiedy z dnia na dzień zmienna zależna może się przekształcić w niezależną, gdy uchwycony w danym momencie dla potrzeb analitycznych stan świata jest inny od tego, gdy książka czy artykuł się ukazuje, nie możemy nadal polegać na znanych nam narzędziach badawczych.

Warto się zastanowić, czy nie mamy właśnie do czynienia z jakimś nowym cyklem cywilizacyjnym. Cywilizacja zaczęła się od zbieractwa, myślistwa, przez hodowlę, uprawę, wydobycie surowców i przetwórstwo przemysłowe. Dziś też przechodzimy od „zbieractwa danych”, przez „fermy danych", kopalnictwo danych (data mining), do przetwórstwa danych (processing) w informacje i wiedzę itp. Innym przykładem może być postfordyzm/ posttayloryzm, czyli kres wytwórczości zdominowanej przez algorytm taśmy produkcyjnej. Przepływy pracy łatwo rejestrowanej dzięki digitalizacji, które jako żywo przypominają taśmę, choć tym razem już cyfrową. Zgodnie z tym cyklem obecnie jesteśmy w fazach nadzoru, kontroli, które ograniczają zdobytą dzięki Oświeceniu wolność, autonomię jednostki i in., ale ludzie znowu jej zapragną i wyzwolą się z mechanizmów monitorowania, nadzoru i innych negatywnych stron cyfryzacji wszystkiego.

\section{/// Zakończenie}

W latach 90. myślenie o przyszłości organizowały dwa scenariusze: jeden - Francisa Fukuyamy (wyd. polskie 2009) - zapowiadał koniec historii triumf liberalnej gospodarki i demokracji na skalę globalną; drugi - Samuela Huntingtona (wyd. polskie 2008) - starcie cywilizacji, które w wersji Benjamina Barbera (wyd. polskie 2007) miało przybrać postać konfliktu między Dżihadem i McŚwiatem. Rozwój wydarzeń w następnych dekadach pokazal, że końca historii nie widać. Wiele procesów dziejących się na naszych oczach pokazuje, że scenariusz Huntingtona zawiera ziarno prawdy, mamy do czynienia z kryzysem „pogodnej” wielokulturowości i narastającymi konfliktami na tym tle z różnym nasileniem w różnych punktach globu. Ale można tylko spekulować, czy oznacza to kres globalizacji i retrybalizację świata, czy globalny populizm, jakąś rewoltę ludowa, w której czynnik etnokulturowy jest tylko jednym z wielu. 
Przed socjologia staje pytanie, czy świat cyfrowy jest uzupełnieniem społeczeństwa, czy nowym społeczeństwem, czy może jest nowym sztucznym żywiołem albo też Nową PlaNETa, której nie można z niczym porównać. Tego jeszcze nie wiemy, ale można się pocieszać, że druk czekał kilkaset lat, aby go oswoić i zdać sobie sprawę z wielkości zmiany społecznej i kulturowej, jaką przyniósł.

Nowe światy tworzą nowych ludzi, stwierdza David Weinberger (2003). Nie jesteśmy w stanie zdefiniować siebie bez nakreślenia obrazu naszego świata, a zarazem nie możemy go opisać bez stwierdzenia, kim jesteśmy jako ludzie. Kiedy pojawia się nowa rzeczywistość, kiedy wkraczamy do nowego świata, stajemy się nowymi ludźmi. Nowi ludzie w nowym świecie nie bardzo wiedza, jak się w nim poruszać, a nie mogą się dowiedzieć od starszych pokoleń, ponieważ one zostały ukształtowane w innej epoce.

Socjologia dziś stanęła poniekąd przed takim samym zadaniem jak u swych narodzin, kiedy przyszło jej badać wielką zmianę społeczną, jaka się dokonywała pod wpływem industrializacji. Jednym ze słów kluczowych była anomia jako skutek zderzenia starych struktur, społeczeństwa statusowego z modernizacją. Dziś znowu relacje technologie-społeczeństwo po 2008 roku rozważa się w kontekście kryzysu. Kryzys ostatniej dekady, który jeszcze długo ciążyć będzie na przyszłości, można pojmować jako mniej lub bardziej traumatyczne i turbulentne przejście od oswojonego mentalnie, kulturowo, instytucjonalnie starego ładu, od jednego komfortu egzystencjalnego (przewidywalne zachowania głównych aktorów, spójne koncepcje, kodeksy) do nowego ładu. Przejście to charakteryzuje ontologiczna niepewność, przeświadczenie, że na każdym kroku czyha ryzyko, chaos intelektualny, kognitywny i moralny, niewiara w utopie ładu i spójnego systemu, frustracja, uogólnione lęki, dezorganizacja kultury, nieprzewidywalne zachowania, intelektualne samoograniczenia, ucieczka w teraźniejszość - igrzyska, banalne produkty, gadżety, jednotygodniowe trendy, modne koncepcje, małe narracje, malejący popyt na rozwiązywanie wielkich problemów społecznych, ucieczka od wizji.

Tak było dotychczas, ale czy tak samo będzie i tym razem? Pozostaje (na razie) bez odpowiedzi pytanie, czy nie będziemy mieli do czynienia $z$ nieładem, który trzeba uznać za normę, a nie stan przejściowy. Oznaczałoby to, że jesteśmy skazani na permanentny kryzys, co brzmi oksymoronicznie. Być może takie igraszki słowne, które można znaleźć w pracach socjologicznych opisujących m.in. postkomunistyczną transformację (Ewolucja od zorganizowanego bezładu do niezorganizowanego ładu, Rychard 1998: 57-58), 
sa jedynym sposobem opisu policentrycznych i chaotycznych struktur złożonych.

Dotychczasowe metody prognostyczne moga nie satysfakcjonować badacza procesów społecznych, ale mają wartość aplikacyjną w konstruowaniu systemów wczesnego ostrzegania i można ich użyć do symulacji przyszłych stanów w postaci koła kryzysów czy katastrof. Jest to po prostu ruletka, na której zamiast kwot wygranych umieszczane są wszelkie typy kryzysów i katastrof, z jakimi dana organizacja mogłaby zostać skonfrontowana (Mitroff, Alpaslan 2003). Każde zatrzymanie wskazówki (pointera) na jednym $z$ nich uruchamia działania antykryzysowe. W takim ujęciu kryzys jawi się jako zmiana, która wymaga szybkiej reakcji i adaptacji. Jak dowodzą Carmeli i Schaubroeck, dzisiejsze kryzysy mają niski stopień prawdopodobieństwa i przewidywalności. Często na niewiele się przydaja wiedza i doświadczenie minionych klęsk i niepowodzeń, które nie wzmacniaja gotowości do zmierzenia się z sytuacją kryzysową (Carmeli, Schaubroeck 2008). Niewiele pomagają wielkie złoża danych nazywanych Big Data, ciagle bowiem brak wydajnych i skutecznych narzędzi analitycznych, agregacyjnych i in.

Na koniec zadajmy pytanie, czy nie mamy do czynienia z utopią postliberalnego świata? Byłaby ona nie pierwszą i nie ostatnią. Było ich bez liku: Morus, Campanella, Owen, Marks, chrześcijańska utopia ładu oparta na miłości bliźniego. Nie były pozbawione utopijnego pierwiastka zrodzone z rewolucji umysłowej i przemysłowej technokratyczne wizje świata zaplanowanego i zarządzanego nauką i technika jak taśma produkcyjna. Niemieckiemu filozofowi Peterowi Sloterdijkowi Kryształowy Pałac w londyńskim Hyde Parku, wybudowany w połowie XIX wieku na potrzeby wystawy światowej, wyposażony we wszystkie cuda ówczesnej techniki, jawił się jako metafora, a zarazem utopia bezpiecznego świata, odpornego na kaprysy przyrody, nieprzewidywalność i ryzyko.

Dziś ta utopia przyjmuje postać „cyfrowego nieba”. Wróciła nadzieja na powtórkę bezpiecznego świata w wersji owego „cyfrowego nieba” powłoki ziemi, z orbity której widać wszystko, co się dzieje w ziemskim ekosystemie - przyrodzie i społeczeństwie - dzięki wszelkiego rodzaju wyświetlaczom, sensorom, kontrolerom, mikrotransmiterom, aktuatorom, mikronawigatorom, bikonom i innym, które zmuszaja ludzi, przyrodę, domy i rzeczy do „mówienia”. Pokolenie dziś przychodzące na świat rozpocznie dorosłe życie w rzeczywistości, w której inteligentne sieci oplotą planetę niczym skóra. Czujniki rozmieszczone wszędzie będą przekazywać 
wszelkie informacje wprost do sieci jak nerwy transmitujące postrzeżenia i informacje do mózgu.

Ziemia będzie wtedy inną, nie wiadomo - lepszą czy gorszą - planetą.

Bibliografia:

/// Anderson Ch. 2009. Long Tail. Why the Future of Business is Selling Less of More, Hyperion.

/// Attali J. 2007. Une breve histoire de l'avenir, Fayard.

/// Barabási A.L., Jeong H., Néda Z., Ravasz E., Schubert A., Vicsek T. 2002. Evolution of the social network of scientific collaborations, „Physica A: Statistical Mechanics and its Applications", t. 311, nr 3-4.

/// Barabási A.L. 2010. Bursts. The Hidden Pattern Behind Everything We Do, Penguin Group.

/// Barber B. 2007. Dìihad kontra McŚwiat, tłum. H. Jankowska, WWL MUZA.

/// Barney D.D. 2008. Społeczeństwo Sieci, tłum. M. Fronia., Sic!.

/// Baudrillard J. 2001. Rozmowy przed końcem, tłum. R. Lis, Sic!.

/// Beck U., Giddens A., Scott L. 2009. Modernizacja refleksyjna, tłum. J. Konieczny, Wydawnictwo Naukowe PWN.

/// Beniger J. 1986. The Control Revolution. Technological and Economic Origins of the Information Society, Harvard University Press.

/// Carmeli A., Schaubroeck J. 2008. Organisational Crisis-Preparedness: The Importance of Learning from Failures, http://www.sciencedirect.com/science?; dostęp: 17.03.2008.

/// Bobryk J. 2014. Transhumanizm, cognitive science i wyzwania dla nauk spotecænych, „Studia Socjologiczne”, nr 3(214), s. 9-27.

/// Brockman J. i in. 2005. Nowy renesans. Granice nauki, tłum. P.J. Szwajcer, A. Eichler, CiS.

/// Buchanan M. 2010. Social Networks. The Great Tipping Point Test, „Social Scientist, Magazine Issue", 2770, 26 of July. 
/// Castells M. 2006. Społeczeństwo sieci, tłum. M. Marody, Wydawnictwo Naukowe PWN.

/// Deleuze G., Guattari F. 1987. A Thousand Plateaus. Capitalism and Schizophrenia, University of Minneapolis Press.

/// Dijk J. 2010. Spokeczne aspekty nowych mediów, tłum. J. Konieczny, PWN.

/// Flusser V. 1987. How we are programmed, za P. Wiatr: Viléma Flussera teoria kultury:komunikacja, media społeczeństwo, praca doktorska w Maszynopisie, UMCS, Lublin 2017.

/// Frase P. 2016. Four Scenarios. Life After Capitalism, Verso.

/// Fukuyama F. 2009. Koniec historii, tłum. T. Bieroń, M. Wichrowski, Znak.

/// FuturICT Project. 2016 http://www.futurict.eu/the-project; dostęp: 17.09.2016.

/// Gibson W. 2005. Pattern recognition, Berkley Publishing.

/// Gladwell M. 2002. The Tipping Point: How Little Things Can Make a Big Difference, Back Bay Books.

/// Harari N.Y. 2016. On Homo Deus, immortality, Dataism and health, the „infinite market”, wywiad dla DW Made for Minds, http://www.dw.com/ en/harari-on-homo-deus-immortality-dataism-and-health-the-infinitemarket/a-19523293; dostęp: 7.02.2018.

/// Harari Y.N. 2017. Dataism Is Our New God, „New Perspective Quarterly", 15.05.2017.

/// Huxley J. 1935. Can sociology become a science?, „Saturday Review of Literature", nr 12 (13), s. 3-4, 14-15.

/// Huntington S. 2008. Zderzenie Cywilizacji, tłum. H. Jankowska, WWL Muza.

/// Gartner Report. 2016, http://www.computerworld.pl/news/403534/ Gartner. zapowiada.nadejscie.nowego.modelu.gospodarczego.html; dostęp: 16.05.2016.

/// Kahn H., Wiener A. 1967. The Year 2000: A framework for speculation on the Next Thirty-Three Years, Collier Macmillan Ltd. 
/// Krzysztofek K. 2016. Sprawczość ludøea, transludzka i postludzka w społeczensstwie nasyconym technologicznie, [w:] Moc sprawcza ludzi i organizacji, red. L.W. Zacher, Poltext sp. z o.o.

/// Kwon D. 2018. Samouczqce się roboty, „Świat Nauki”, kwiecień, nr 4(320).

/// Latour B. 1996. On Actor Network. Theory. A Few Clarifications, „Soziale Welt", t. 47, nr 4.

/// Lem S. 2009. Fantastyka i Futurologia, t. 1, Agora.

/// Marody M., Rafałowicz M. 2007. Sié́ z du̇̇ymi dziurami, http://technopolis.polityka.pl/2007/rozmowa-z-miroslawa-marody-o-spoleczenstwieinformatycznym; dostęp: 08.06.2014.

/// Meadows D.H., Meadows D.L., Randers W.J., Behrens W. 1973. Granice wzrostu, Państwowe Wydawnictwo Ekonomiczne.

/// Mayer-Schoenberger V., Cukier K. 2013. Big Data. A Revolution that will Transform how we live, work and think, Eamon Dolan/Mariner Books.

/// Mitroff I.I., Alpaslan M.C. 2003. Przygotuj sie na katastrofe, „Gazeta Wyborcza”, 17.11.2003.

/// Morin E. 1981. Pour sortir du XXe siècle, Seuil.

/// Morozov E. 2013. To Save Everything, Click Here: Technology, Solutionism, and the Urge to Fix Problems that don't Exist, Allen Lane.

/// Pentland A. 2015. Social Pbysics: How Social Networks Can Make Us Smarter, Penguin Books.

/// Postman N. 2001. W strone XVIII stulecia. Jak pržesz̧tość może doskonalić naszaprzysztość, tłum. R. Frąc, PIW.

/// Rifkin J. 2001. Schytek sity roboczej na świecie i poczatek ery postrynkowej, tłum. E. Kania, Wydawnictwo Dolnośląskie.

/// Rychard A. 1998. Ewolucja od zorganizowanego bezładu do niezorganizowanego Ładu, [w:] Do i od socjalizmu, red. A. Siciński, IFiS PAN.

/// Salganik M.J., Watts D.J. 2009. Web-Based Experiments for the Study of Collective Social Dynamics in Cultural Markets, „Topics in Cognitive Science”, nr 1(3), s. 439-468.

/// Simon J. 1981. The Ultimate Resource, Princeton University Press. 
/// Sitaram A., Huberman B.A. 2010. Predicting the Future with Social Media http://arxiv.org/PS_cache/arxiv/pdf/1003/1003.5699v1.pdf; dostęp: 7.03. 2018.

/// Snow Ch.P. 1993. The Two Cultures, Cambridge University Press.

/// Taleb N.N. 2015. Czarny tabę‡: O skutkach nieprzenidywalności żdarzeńn, tłum. O. Siara, Kurhaus Publishing.

/// Touraine A. 2013. La fin des sociétés, Seuil.

/// Weinberger D. 2003. Small Pieces Loosely Joined: A Unified Theory of the Web, Basic Books.

/// World Economic Forum, 2015. Deep Shift. Technology Tipping Points and Societal Impact, https://www.weforum.org/reports/deep-shift-technologytipping-points-and-societal-impact; dostęp: 28.01.2018.

/// Wójcik A. 2018. Gdrie siepodziało moje ciało. O rapomnianej/zagubionej somie, http://www.anthropos.us.edu.pl/anthropos2/texty/wojcik.htm; dostęp: 14.01.2018.

\section{/// Abstrakt}

Zdaniem autora panuje niewiara w możliwość przewidywania przeszłości, ponieważ z reguły nie udaje się jej przewidzieć. Wymyślano w przeszłości wiele scenariuszy, aby obniżyć barierę postrzegalności nowych zjawisk. Im więcej scenariuszy, tym większe prawdopodobieństwo, że jeden z nich okaże się trafiony, ale tym większa niepewność, który. Socjologia pomna swych porażek w przeszłości utraciła wiarę w swój potencjał predykcyjny, utożsamiając predykcję ze spekulacją. Narasta przekonanie, że sami data scientists sobie poradzą, mając do dyspozycji wielkie złoża Big Data. Nie potrzeba im socjologów ani innych specjalistów dziedzinowych, bo sami uporają z interpretacją danych, i potrafią dostarczyć odpowiednich policy czy business oriented recommendations. Autor sądzi, że socjologia ma nadal niebagatelne zasoby, ale musi przekonać, także samą siebie, że bez niej nie poradzą sobie data scientists. Ten potencjał socjologii dostrzegaja niektórzy przedstawiciele nauk ścisłych, zdaniem których nauki społeczne przestana być „ubogim krewnym”. Coraz więcej badań socjologicznych przynosi interesujące rezultaty, także w sferze przewidywania zachowań społecznych. 
Słowa kluczowe:

przyszłość, technologie informacyjne, prognozowanie, złożoność, datascience.

\section{/// Abstract}

There is less and less faith as to the possibility of forecasting since the rules of doing this are increasingly fallible. In the past many scenarii have been conceptualised in order to lower the barier of perception of the new phenomena. The more such scenarii are applied the bigger is the plausibility that one of these might be true, yet the more uncertainty which one. Sociology aware of its defeats in the past lost its faith in predictive potential to avoid repproach of being speculative. There is an increasing conviction that data science and scientists will manage to do it having Big Data at their disposal. Data scientists believe that neither socologists nor any other field experts in social sciences are necessary as data scientists themselves will do to interpret data and succeed in delivering appropriate and relevant policy and business oriented recommendations. The author claims our discipline is still in possession of important resources but sociologists should persuade themselves, the data science can do little without their assistance. The potential of sociology in forecasting is being confirmed by some „hard” scientists. More and more sociological research bring interesting and promising results in forecasting the social behaviour.

Keywords:

futures, IT, forecasting, complexity, data science

/// Kazimierz Krzysztofek - profesor nadzwyczajny w Uniwersytecie SWPS w Warszawie; wieloletni wykładowca (do 2016 r.) w Polsko-Japońskiej Akademii Technik Komputerowych; w latach 1995-2006 członek Komitetu Prognoz PAN Polska 2000 Plus. Staż podoktorski w Massachusetts Institute of Technology w zakresie badań nad mediami i komunikacja, gościnny wykładowca w College of Liberal Arts, Pennsylvania State University, autor publikacji z zakresu społeczeństwa informacyjnego i sieciowego, socjologii Internetu, nowych mediów i przemysłów kultury oraz komunikacji międzykulturowej.

Email:kkrzysz1@swps.edu.pl 